\title{
The Effect of Profitability, Leverage, Liquidity, Size, and Company Growth on the Dividend Payout Ratio in the Indonesian Capital Market 2013-2018
}

\author{
Anjumul Azhariyah ${ }^{1}$, Andre Dwijanto Witjaksono², Ulil Hartono ${ }^{3}$ \\ 1,2,3 Management Study Program, Universitas Negeri Surabaya, Indonesia \\ anjumul.18007@mhs.unesa.ac.id
}

\begin{abstract}
This study aims to determine and analyze the effect of Profitability, Leverage, Liquidity, Size, and Company Growth on Dividend Payout Ratio in the Indonesian capital market 2013-2018. The population of this research is 525 companies from all sectors listed on the IDX except for the finance sector. By using purposive sampling method, the number obtained is 10 companies. The data testing method used is multiple linear regression analysis. The results showed that simultaneously the variables of profitability, leverage, liquidity, size and company growth had no effect on the dividend payout ratio. Partially, profitability, leverage, liquidity, company size have no effect on the dividend payout ratio, while the company growth variable has a significant negative effect on the dividend payout ratio.
\end{abstract}

Keywords

profitability, leverage; liquidity, company size; company grouth; dividend payout ratio

\section{Introduction}

The Capital Market is a place for investors to invest funds in the form of stocks or valuable assets with the aim of maximizing the wealth obtained through dividends. Not all of the companies listed on the IDX distribute dividends to investors, either in the form of cash dividends or shares. Dividend policy is a decision that the profit earned by the company will be distributed to shareholders as dividends or will be retained to finance investments in the future (Sartono, 2001). Dividend policy in this study uses a dividend payout ratio (DPR).

Dividend Payout Ratio is the ratio of the percentage of net profit after tax that will be received by investors in the form of dividends (Sudana, 2011). Companies that decide to distribute profits to investors as dividends will reduce the amount of retained earnings which in turn reduces the sources of funds that the company will use to develop the company.

Not all of the companies listed on the IDX (Indonesia Stock Exchange) distribute dividends to investors, either in the form of cash dividends or stock dividends. This is due to the company's consideration in making dividend payment policies to investors or shareholders. It is proven that the data obtained from the annual report of the Indonesia Stock Exchange (IDX) for the period 2013-2018. Some companies don't even pay dividends. Table 1.1 explains the total data of companies that distributed dividends from eight sectors on the IDX (Indonesia Stock Exchange) in 2013-2018. 
Table 1. Results of the Recap of Dividend Distribution in 2013-2018

\begin{tabular}{|c|c|c|}
\hline Period & $\begin{array}{c}\text { Not Distributing } \\
\text { Dividends }\end{array}$ & $\begin{array}{c}\text { Share } \\
\text { Dividend }\end{array}$ \\
\hline 2013 & 482 & 43 \\
\hline 2014 & 419 & 106 \\
\hline 2015 & 384 & 141 \\
\hline 2016 & 363 & 162 \\
\hline 2017 & 343 & 182 \\
\hline 2018 & 493 & 32 \\
\hline
\end{tabular}

Source: IDX, 2020 (data processed)

The table describes the number of companies that distributed dividends in 2013 to 2018 from eight sectors on the IDX (Indonesia Stock Exchange). In 2013, of all existing sectors, only 43 companies distributed dividends; in 2014 increased to 106 companies distributing dividends; whereas in 2015 the number of companies distributing dividends continued to increase, reaching 141 and continuously increasing until 2017. However, in 2018 , the number of companies distributing dividends has decreased again to only 32 companies that distribute dividends.

This research is also motivated by a research gap between the results of previous studies briefly in table 2 . The results of the research presented in the table indicate that with regard to the dividend payout ratio, there are several factors that influence it. These factors are Profitability, Leverage, Liquidity, Size and Company Growth. However, the results of these studies still provide different results, so they need to be investigated further. Based on the description above, the researchers are interested in reexamining the effect of profitability, leverage, liquidity, size, and company growth on dividend payout ratio in Indonesian capital market 2013-2018.

This research is expected to be useful for several parties, such as investors so that it can help and become a consideration in making investments. The company is expected to be able to assist the company as a matter of consideration in determining dividend payments.

\section{Review of Literatures}

\subsection{Dividend Policy}

Optimal dividend policy is a policy that contains a balance between current dividends and future growth that maximizes the company's share price. If a company increases the percentage of income that will be paid to shareholders as a cash dividend (dividend payout ratio), the share price will increase. This is because the dividend policy gives an impression to investors that the company has good prospects in the future (Sandy \& Asyik, 2013). The size of dividends paid to shareholders depends on the dividend policy of each company, not all companies pay dividends to investors, because they want to hold the company's profits for other purposes.

Profitability is the ratio of comparison to determine the company's ability to earn profits in relation to sales, total assets, and own capital. In this study, profitability uses the proxy return on assets (ROA). If the level of company profitability is high, the greater the profit generated by the company will be distributed in the form of dividends to investors (Ginting, 2018). Previous research has shown that profitability has a significant positive effect on the dividend payout ratio, but other studies have shown that profitability has no effect on the dividend payout ratio. 
Leverage is the company's ability to fulfill its obligations which can be shown by how much debt payments use its own capital. This study uses the proxy Debt to Equity Ratio (DER). This variable becomes the benchmark for the company in distributing dividends to investors. The higher the leverage of the company, the lower the ability to pay dividends because the number of assets owned by the company are financed by debt so that the net profit earned decreases because it is used to pay increasing debt (Permana \& Hidayati, 2016). Previous studies have shown a significant negative effect on the dividend payout ratio, but other studies have shown that leverage has no effect on the dividend payout ratio o.

The liquidity of the company has a big influence on company investment. The liquidity of a company shows the company's ability to fund the company's operations and pay off its short-term obligations. Companies with good liquidity are likely to have better dividend payments (Wijayantini et al., 2019). According to Afiezan et al (2020) a liquid company means that the company has large funds to pay all of its obligations. The more liquid the company is, the more internal funds it will have to meet its operational needs. In this study, the liquidity variable was measured by the current ratio (CR).

Company size is the value of the size of the company as indicated or valued by total assets, total sales, total profit, tax expense and others so that it affects the company's social performance and causes the achievement of company goals (Brigham \& Houston, 2010). The greater the size of the company, it can guarantee that the company will distribute profits to company owners in the form of dividends or cash.

Company growth Company growth describes the percentage growth of company posts from year to year. This ratio shows the percentage increase in sales this year compared to last year. The higher this ratio, the better (Harahap, 2002). According to Yeniatie \& Destriana (2010), company growth is the rate of change in total assets from year to year; Meanwhile, according to Steven \& Lina (2011), company growth is a description of the company's development. Company growth is measured using changes in total income. Company growth is the difference between total income owned by the company in the current period with the previous period to the total revenue of the previous period

\subsection{Previous Research Review}

Table 2. Research Gap

\begin{tabular}{|c|c|c|c|}
\hline Researchers & Title & Variables & Results \\
\hline Suriani Ginting (2018) & $\begin{array}{l}\text { The Effect of Liquidity, } \\
\text { Profitability \& Leverage } \\
\text { on Dividend Policy at } \\
\text { Lq45 Companies Listed } \\
\text { on the Indonesia Stock } \\
\text { Exchange for the Period } \\
\text { 2012-2016 }\end{array}$ & $\begin{array}{l}\mathrm{Y}: \text { DPR } \\
\mathrm{X}_{1}: \text { Liquidity } \\
\mathrm{X}_{2}: \text { Profitability } \\
\mathrm{X}_{3} \text { : Leverage }\end{array}$ & $\begin{array}{l}\text { Profitability has a positive effect } \\
\text { on the dividend payout ratio, } \\
\text { while the liquidity and leverage } \\
\text { variables have no effect on the } \\
\text { dividend payout ratio. }\end{array}$ \\
\hline $\begin{array}{l}\text { Aggy Eka Ressy \& Anis } \\
\text { Chariri (2013) }\end{array}$ & $\begin{array}{l}\text { The Effect of Financial } \\
\text { Performance on Dividend } \\
\text { Policy on the Indonesian } \\
\text { Stock Exchange }\end{array}$ & $\begin{array}{l}\mathrm{Y}: \text { DPR } \\
\mathrm{X}_{1}: \text { Profitability } \\
\mathrm{X}_{2}: \text { Leverage } \\
\mathrm{X}_{3}: \text { Growth }\end{array}$ & $\begin{array}{l}\text { Profitability, leverage, and } \\
\text { growth have a positive effect on } \\
\text { the dividend payout ratio. }\end{array}$ \\
\hline Mahira Rafique (2012) & \begin{tabular}{|l|} 
Factors Affecting Dividend \\
Payout: Evidence from \\
Listed Non-Financial Firms \\
of Karachi Stock Exchange
\end{tabular} & $\begin{array}{l}\text { Y: DPR } \\
\mathrm{X}_{1} \text { : Profitability } \\
\mathrm{X}_{2} \text { : Company Size }\end{array}$ & $\begin{array}{l}\text { Profitability and firm size have a } \\
\text { positive effect on the dividend } \\
\text { payout ratio }\end{array}$ \\
\hline $\begin{array}{l}\text { S. Franklin John \& } \\
\text { Muthusamy (2010) }\end{array}$ & $\begin{array}{l}\text { Leverage, Growth and } \\
\text { Profitability as Determinants of } \\
\text { Dividend Payout Ratio-Evidence } \\
\text { from Indian Paper Industry }\end{array}$ & $\begin{array}{l}\text { Y: DPR } \\
\mathrm{X}_{1} \text { : Profitability } \\
\mathrm{X}_{2} \text { : Liquidity } \\
\mathrm{X}_{3} \text { : Growth }\end{array}$ & $\begin{array}{l}\text { Profitability, liquidity and } \\
\text { company growth have a negative } \\
\text { effect on the dividend payout } \\
\text { ratio. }\end{array}$ \\
\hline
\end{tabular}




\begin{tabular}{|l|l|l|l|}
\hline H. S. Lestari (2018) & $\begin{array}{l}\text { Determinants of corporate } \\
\text { dividend policy in } \\
\text { Indonesia }\end{array}$ & $\begin{array}{l}\text { Y: DPR } \\
\mathrm{X}_{1} \text { : Profitability } \\
\mathrm{X}_{2} \text { : Leverage } \\
\mathrm{X}_{3} \text { : Size } \\
\mathrm{X}_{4}: \text { Growth }\end{array}$ & $\begin{array}{l}\text { profitability and company growth } \\
\text { have a positive effect. Company } \\
\text { size has a negative effect, while } \\
\text { leverage does not affect the } \\
\text { dividend payout ratio }\end{array}$ \\
\hline
\end{tabular}

\subsection{Hypothesis Test}

Based on the theoretical review, the hypotheses of this study are as follows:

H1: Profitability has a positive effect on the dividend payout ratio in the Indonesian Capital Market for the 2013-2018 period

$\mathrm{H} 2$ : Leverage has a negative effect on the dividend payout ratio in the Indonesian Capital Market for the 2013-2018 period

H3: Liquidity has a positive effect on the dividend payout ratio in the Indonesian Capital Market for the 2013-2018 period

H4: Company size has a positive effect on the dividend payout ratio in the Indonesian Capital Market for the 2013-2018 period

H5: Company growth has a negative effect on the dividend payout ratio in the Indonesian Capital Market for the 2013-2018 period.

\section{Research Methods}

This research is a quantitative study using multiple linear regression analysis method. The sample was taken by using purposive sampling technique. The data in the study used secondary data in the form of annual financial report data and the Indonesian Capital Market Directory (ICMD) on eight sectors listed on the Indonesia Stock Exchange for the period 2013-2018 which were obtained from (www.idx.co.id).

Systematically, the method of multiple linear regression analysis is as follows:

$Y=\mathrm{a}+\mathrm{b} 1 \mathrm{X} 1+\mathrm{b} 2 \mathrm{X} 2+\mathrm{b} 3 \mathrm{X} 3+\mathrm{b} 4 \mathrm{X} 4+\mathrm{b} 5 \mathrm{X} 5+\mathrm{e}$

Explanation:

Y : Dividend Payout Ratio (DPR)

a : Constanta

b1-b4 : Coefficient regression

$\mathrm{X}_{1} \quad$ : Profitability

$\mathrm{X}_{2} \quad$ : Leverage

$\mathrm{X}_{3} \quad$ : Liquidity

$\mathrm{X}_{4} \quad$ : Company Size

$\mathrm{X}_{5}$ : Company Growth

e : Error

\section{Results and Discussion}

\subsection{Classic Assumption Test}

a. Normality Test

Table 3. Normality Test Results

\begin{tabular}{ccc}
\hline & $\begin{array}{c}\text { Unstandardized } \\
\text { Residual }\end{array}$ & Conclusion \\
\hline N & $\mathbf{6 0}$ & Normally \\
$\begin{array}{c}\text { Asymp. Sig. }(2- \\
\text { tailed) }\end{array}$ & 0,788 & Distributed Data \\
\hline
\end{tabular}


Based on the results of the normality test using the Kolmogorov-Smirnov test, the results of data processing show that the data is normally distributed. This can be proven by the K-S test results which show the Asymp results. Sig (2-tailed) above the significance level of 0.05 , which is equal to 0.788 .

\section{b. Multicollinearity Test}

Table 4. Multicollinearity Test Results

\begin{tabular}{|c|c|c|c|}
\hline \multirow[t]{2}{*}{ Variable } & \multicolumn{2}{|c|}{$\begin{array}{c}\text { Collinearity } \\
\text { Statistics }\end{array}$} & \multirow[t]{2}{*}{ Conclusion } \\
\hline & Tolerance & VIF & \\
\hline ROA & 0,458 & 2,186 & $\neq$ Multicollinearity \\
\hline DER & 0,253 & 3,950 & $\neq$ Multicollinearity \\
\hline CR & 0,325 & 3,077 & $\neq$ Multicollinearity \\
\hline SIZE & 0,638 & 1,566 & $\neq$ Multicollinearity \\
\hline GROWTH & 0,955 & 1.047 & $\neq$ Multicollinearity \\
\hline
\end{tabular}

Based on the results of the multicollinearity test, it can be concluded that the results of the torelance value indicate the independent variable with a tolerance value $>0.10$ or equal to VIF <10, therefore the regression model in this study does not occur multicollinearity.

c. Autocorrelation Test

Table 5. Autocorrelation Test Results

\begin{tabular}{ccc}
\hline Model & Durbin-Watson & Conclusion \\
\hline $\mathbf{1}$ & 1,833 & $\neq$ Autocorrelation \\
\hline
\end{tabular}

Table 5 is the result of the autocorrelation test with a Durbin-Watson value of 1.828. Furthermore, the DW values are compared with the dU and 4 - dU values listed in the Durbin-Watson table. The dU value is taken from the DW table with $\mathrm{N}$ amounting to 60 and $\mathrm{K}=5$, so that the $\mathrm{dU}$ is 1.8082 . Decision making is carried out with the provisions $\mathrm{dU}$ $<\mathrm{d}<4-\mathrm{dU}$ or $1.7671<1,833<2,2329$. From these results it can be concluded that the regression model does not contain autocorrelation.

\section{d. Heteroscedasticity Test}

Table 6. Park Test Results (Heteroscedasticity)

\begin{tabular}{ccc}
\hline Variable & Sig & Conclusion \\
\hline ROA & 0,603 & $\neq$ Heteroscedasticity \\
DER & 0,177 & $\neq$ Heteroscedasticity \\
CR & 0,384 & $\neq$ Heteroscedasticity \\
Size & 0,544 & $\neq$ Heteroscedasticity \\
Growth & 0,729 & $\neq$ Heteroscedasticity \\
\hline
\end{tabular}

The probability results are said to be significant if the significance value is above the $5 \%$ confidence. If the significance coefficient is greater than the specified significance level, the table above can be concluded that there is no heteroscedasticity (homoscedasticity) because the significance coefficient is greater than the specified significance, which is $5 \%(0.05)$. 


\subsection{Hypothesis Test}

\section{a. Simultaneous Significance Test (F test statistic)}

The results of the F statistical test can be seen in the following table:

Table 7. Simultaneous Test Hypothesis Testing Results (Test Statistic F)

\begin{tabular}{ccc}
\hline Model & F & Sig \\
\hline Regression & 2,144 & 0,074 \\
\hline
\end{tabular}

Based on the results of the simultaneous test, the calculated $F$ value was 2.144 with a significance level of 0.074 . A significance value greater than 0.05 , it can be concluded that the variables of profitability, leverage, liquidity, size and company growth do not simultaneously affect the dividend payout ratio.

\section{b. Partial Significance Test}

The results of the $t$ statistical test can be seen in the following table:

Table 8. Partial Test Results (t test)

\begin{tabular}{lccc}
\hline \multicolumn{1}{c}{ Variable } & $\mathrm{B}$ & $\mathrm{T}$ & Sig \\
\hline (constant) & 133,779 & 2,165 &, 035 \\
ROA &, 281 &, 742 &, 461 \\
DER & 1,096 &, 095 &, 925 \\
CR &,- 006 &,- 081 &, 936 \\
Size & $-5,262$ & $-1,715$ &, 092 \\
Growth & $-14,941$ & $-2,149$ &, 036 \\
\hline
\end{tabular}

Based on Table 8, it can be concluded as follows:

1) The effect of profitability on the dividend payout ratio

Based on the partial test results, it can be seen that the significance value of profitability as proxied by return on assets (ROA) is $0.461>0.05$. This shows that profitability has no effect on the dividend payout ratio in the Indonesian capital market for the 20132018 period.

2) The effect of Leverage on the dividend payout ratio

Based on the partial test results, it can be seen that the significant value of leverage as proxied by the debt to equity ratio (DER) is $0.925>0.05$. This shows that leverage has no effect on the dividend payout ratio in the Indonesian capital market for the period 2013-2018.

3) The effect of Liquidity on the dividend payout ratio

Based on the partial test results, it can be seen that the significant value of liquidity as proxied by the current ratio $(\mathrm{CR})$ is $0.936>0.05$, indicating that liquidity has no effect on the dividend payout ratio in the Indonesian capital market for the period 2013-2018.

4) The effect of company size on the dividend payout ratio

Based on the results of the partial test, it can be seen that the significant value of the company size is proxied by size is $0.092>0.05$. This shows that company size has no effect on the dividend payout ratio.

5) The Effect of Company Growth on the dividend payout ratio

Based on the partial test results, it can be seen that the significant value of growth is $0.036<0.05$, which means that company size has an effect on the dividend payout ratio in the Indonesian capital market for the period 2013-2018. 


\section{c. Coefficient of Determination $\left(\mathbf{R}^{2}\right)$}

The results of the determination coefficient test can be seen in the following table:

Table 9. Test Results of the Determination Coefficient $\left(\mathrm{R}^{2}\right)$

\begin{tabular}{ccccc}
\hline Model & $\mathrm{R}$ & R Square & $\begin{array}{c}\text { Adjusted } \\
\text { R Square }\end{array}$ & $\begin{array}{c}\text { Std. Error of the } \\
\text { Estimate }\end{array}$ \\
\hline $\mathbf{1}$ & 0,407 & 0,166 & 0,088 & 30,81878 \\
\hline
\end{tabular}

The results of the calculation of the regression coefficient in this study obtained the $\mathrm{R}$ Square value of 0.166 . This means that all independent variables consisting of profitability, leverage, liquidity, size and company growth are able to explain the model, the remaining $16.6 \%$ is explained by other factors that are not included in the research model.

\subsection{Discussion}

1. The effect of profitability on the dividend payout ratio

The results of this study indicate that profitability, which is proxied by return on assets, has a positive but insignificant effect on the dividend payout ratio in the Indonesian capital market for the 2013-2018 period. The results of this study are supported by previous research, namely, Deitiana (2009), and Permana \& Hidayati (2016); but contrary to the results of research by Ginting (2018), Ingrit et al. (2017), Damayanti et al. (2017) Ahmad \& Wardani (2014), Rafique (2012), Suroto (2015), and Mehta (2012) which state that profitability affects the dividend payout ratio. This shows that companies with small profitability are also able to pay larger dividends than companies with large profitability. So that the amount of profitability does not guarantee that the company will pay large dividends. It can be said that the size of the profitability does not affect the ups and downs of dividend distribution.

2. The effect of leverage on the dividend payout ratio

The results of this study indicate that leverage proxied by the debt to equity ratio has a positive but insignificant effect on the dividend payout ratio in the Indonesian capital market for the period 2013-2018. The results of this study are supported by previous research by Ma'rufatin \& Purwohandoko (2018), Ginting (2018), and Mehta (2012); but contrary to the research results of Suroto (2015), Permana \& Hidayati (2016), and Fitriana \& Suzan (2018) which state that leverage affects the dividend payout ratio. This proves that the high amount of debt does not prevent the company from distributing dividends because the company also pays attention to the interests of the owners of capital.

3. The effect of liquidity on the dividend payout ratio

The results of this study indicate that liquidity, which is proxied by the current ratio, has a negative but insignificant effect on the dividend payout ratio in the Indonesian capital market for the 2013-2018 period. The results of this study are supported by research by Ginting (2018), Deitiana (2009), and Mehta (2012); but contrary to the research results of Ingrit et al. (2017), Rehman \& Takumi (2012), Ahmad \& Wardani (2014), which state that liquidity affects the dividend payout ratio. This proves that companies that have good liquidity do not necessarily mean that dividend payments are better.

4. The effect of company size on the dividend payout ratio

The results of this study indicate that company size as proxied by Size has a negative but insignificant effect on the dividend payout ratio in the Indonesian capital 
market for the period 2013-2018. The results of this study contradict the results of research conducted by Ma'rufatin \& Purwohandoko (2018), Ahmad \& Wardani (2014), Rafique (2012), Nurhayati (2013), Lestari (2018), and Suroto (2015) which state that there is an influence between the size of the company to the dividend payout ratio. However, this research is supported by Sari (2015) which states that company size has no effect on the dividend payout ratio. The results of this study indicate that the large number of assets owned by large companies is not necessarily a guarantee for making dividend payments to investors.

5. The effect of company growth on the dividend payout ratio

The results of this study indicate that company growth has a significant negative effect on the dividend payout ratio in the Indonesian capital market for the period 20132018. The results of this study are supported by research results from John \& Muthusamy (2010), Permana \& Hidayati (2016), and Ressy \& Chariri (2013) which state that there is an influence between company growth and dividend payout ratio. However, this study contradicts the results of research from Ma'rufatin \& Purwohandoko (2018), Samrotun (2015), and Sari (2015) which state that company growth has no effect on the dividend payout ratio. The results of this study prove that there is an effect between the growth of the company on the dividend payout ratio, because the faster the growth rate of a company, the greater the need for funds in the future to finance its growth.

\section{Conclusion}

Simultaneously: profitability, leverage, liquidity, company size and growth have no significant effect on the dividend payout ratio in the Indonesian capital market for the period 2013-2018. Partially: profitability, leverage, liquidity, company size does not affect the dividend payout ratio; while the company growth variable has a significant negative effect on the dividend payout ratio. The R Square value is 0.166 , which means that the independent variable consisting of profitability, leverage, liquidity, size and company growth is able to explain the $16.6 \%$ model for the dependent variable, namely the dividend payout ratio, while the rest is explained by other factors that are not included in the research model.

\section{Suggestions}

1. Further research is expected to increase the number of samples by extending the observation period and can use other indicators, namely the dividend yield ratio.

2. It is hoped that in future studies it can add other variables or proxies that may be factors that affect the dividend payout ratio, for example investment opportunities, managerial ownership capital structure, and others; so that it can provide a broader picture of what factors can affect the dividend payout ratio. 


\section{References}

Afiezan, A., et al. (2020). The Effect of Free Cash Flow, Company Size, Profitability and Liquidity on Debt Policy for Manufacturing Companies Listed on IDX in 2016-2019 Periods. Budapest International Research and Critics Institute-Journal (BIRCIJournal). P. 4005-4018.

Ahmad, G. N., \& Wardani, V. K. (2014). The Effect of Fundamental Factor To Dividend Policy: Evidence in Indonesia Stock Exchange. International Journal of Business and Commerce, 4(02), 14-25.

Brigham, E. F., \& Houston, J. F. (2010). Dasar-Dasar Manajemen Keuangan Essentials of Financial Management (11th ed.). Salemba Empat.

Damayanti, R., Marwati, F. S., \& Widayanti, R. (2017). Analisa Kebijakan Dividen Berdasarkan Teori Lintner. Jurnal Ekonomi Dan Bisnis, 1(2), 183-194. https://doi.org/10.22236/agregat

Deitiana, T. (2009). Faktor-Faktor Yang Mempengaruhi kebijakan divident cash. Jurnal Bisnis Dan Akuntansi, 11(1), 57-64.

Fitriana, Y. A., \& Suzan, L. (2018). The Influence of Agency Cost, Profitability, and Debt to Equity Ratio (DER) On Dividend Policy: A Study on Basic Industry and Chemicals Listed in Indonesian Stock Exchange during 2012-2016. Jurnal Pendidikan Bisnis Dan Ekonomi, 4(1), 77-86.

Ginting, S. (2018). Pengaruh Likuiditas, Profitabilitas. Dan Leverage Terhadap Kebijakan Deviden Pada Perusahaan LQ45 Yang Terdaftar Di Bursa Efek Indonesia Periode 2012-2016. Jwem Stie Mikroskil, 8(2), 195-204.

Harahap, S. S. (2002). Analisa Kritis Atas Laporan Keuangan. PT Raja Graffindo Persada.

Ingrit, Siregar, H., \& Syarifuddin, F. (2017). Factors Influencing Dividend Policy on Mining Companies Listed in Indonesia Stock Exchange 2011-2015. International Journal of Administrative Science \& Organization, 24(2), 91-99.

John, S. F., \& Muthusamy, K. (2010). Leverage, Growth and Profitability as Determinants of Dividend Payout Ratio-Evidence from Indian Paper Industry. Asian Journal of Business Management Studies, 1(1), 26-30.

Lestari, H. S. (2018). Determinants of corporate dividend policy in Indonesia. IOP Conference Series: Earth and Environmental Science, 106(1). https://doi.org/10.1088/1755-1315/106/1/012046

Ma'rufatin, R., \& Purwohandoko. (2018). The Influence of Profitability, Sales Growth , Leverage , Company' s Size, and Free Cash Flow Toward Dividend Policy: A Study on Infrastructure Sector Companies, Utility , and Transportation Listings IDX 2010-2014 Period. Journal Research Opinion, 5(11), 2297-2308.

Mehta, A. (2012). An Empirical Analysis of Determinants of Dividend Policy - Evidence from the UAE Companies. Global Review of Accounting and Finance, 3(1), 18-31.

Nurhayati, M. (2013). Profitabilitas Likuiditas dan Ukuran Perusahaan Pengaruhnya Terhadap Kebijakan Dividen dan Nilai Perusahaan Sektor Non Jasa. Jurnal Keuangan Dan Bisnis, 5(2), 144-153.

Permana, H.A., \& Hidayati, L. . (2016). Analisis Pengaruh Leverage, Likuiditas, Profitabilitas, Pertumbuhan Perusahaan dan Ukuran Perusahaan Terhadap Kebijakan Dividen Pada Perusahaan Manufaktur Yang Terdaftar Di BEI. Jurnal Manajemen Bisnis Indonesia (JMBI), 648-659.

Rafique, M. (2012). Factors Affecting Dividend Payout: Evidence From Listed NonFinancial Firms of Karachi Stock Exchange. Business Management Dynamics, 1(11), 76-92. 
Rehman, A., \& Takumi, H. (2012). Determinants of Dividend Payout Ratio: Evidence From Karachi Stock Exchange (KSE). Journal of Contemporary Issues in Business Research, 1(1), 20-27.

Ressy, A. E., \& Chariri, A. (2013). Pengaruh Kinerja Keuangan terhadap Kebijakan Dividen di Bursa Efek Indonesia. Journal Of Accounting, 2(4), 1-10.

Samrotun, Y. C. (2015). Kebijakan Dividen dan Faktor-faktor yang Mempengaruhinya. Jurnal Paradigma, 13(01), 92-103.

Sandy, A., \& Asyik, N. F. (2013). Pengaruh Profitabilitas Dan Likuiditas Terhadap Kebijakan Dividen Kas Pada Perusahaan Otomotif. Jurnal Ilmu \& Riset Akuntansi Vol., 1(1), 58-76.

Sari, S. E. (2015). Pengaruh Ukuran Perusahaan, Likuiditas, Profitabilitas, Pertumbuhan Perusahaan, Dan Kepemilikan Institusional Terhadap Kebijakan Devidend Payout Ratio (Dpr). EKOMBIS REVIEW: Jurnal Ilmiah Ekonomi Dan Bisnis, 2(2), 231242. https://doi.org/10.37676/ekombis.v2i2.18

Sartono, A. (2001). Manajemen Keuangan Teori dan Aplikasi (4th ed.). BEF.

Steven, \& Lina. (2011). Faktor-Faktor Yang Mempengaruhi Kebijakan Hutang Perusahaan Manufaktur. Jurnal Bisnis Dan Akuntansi, 13(3), 163-181.

Sudana, I. M. (2011). Manajemen Keuangan Perusahaan Teori dan Praktik. Erlangga.

Suroto. (2015). Faktor-faktor Yang Mempengaruhi Dividend Payout Ratio Pada Perusahaan Yang Terdaftar Di Bursa Efek Indonesia Periode 2010-2012. E-Jurnal Serat Acitya, 18-32.

Wijayantini, B., Sari, M. I., \& Arif, A. (2019). The Analysis Of ROA,Current Ratio, and Debt To Equity Ratio To The Dividen Policy Of Financing Firm: The Case Of Indonesian Stock Exchange. Manajemen Dan Bisnis Indonesia, 5, 239-246.

Yeniatie, \& Destriana, N. (2010). Faktor - Faktor Yang Mempengaruhi Kebijakan Hutang Pada Perusahaan Non Keuangan Yang Terdaftar Di Bursa Efek Indonesia. Jurnal Bisnis Dan Akuntansi, 12(1), 1-16. https://doi.org/10.25105/jmat.v1i1.4904 